\title{
Brand Rebranding, Brand Associations, Customer Satisfaction, \\ Company Reputation dan Customer Loyalty
}

by

\author{
I Putu David Aritona ${ }^{(1)}$ \\ Ni Putu Nina Eka Lestari ${ }^{(2)}$ \\ PT. Asuransi Jasa Indonesia (Persero) ${ }^{(1)}$ \\ Universitas Pendidikan Nasional ${ }^{(2)}$ \\ davidaritona@ymail.com ${ }^{(1)}$ \\ niputuninaekalestari@yahoo.com ${ }^{(2)}$
}

\begin{abstract}
The purpose of this study was to determine the effect of corporate rebranding, on brand associations, customer satisfaction, company reputation and customer loyalty. The study was conducted at Jasindo Insurance Denpasar. The technique of collecting data uses a questionnaire to 100 customers of Jasindo Insurance Denpasar. Data were analyzed by Structure Equation Modeling data analysis with AMOS program. The results of the study show that there is corporate rebranding that has a positive and significant effect on brand associations, customer satisfaction and company reputation. Besides that there is also a positive and significant influence between corporate rebranding brand associations, customer satisfaction and the company's reputation for customer loyalty.
\end{abstract}

Keywords: corporate rebranding brand associations, customer satisfaction, company reputation and customer loyalty

\begin{abstract}
ABSTRAK
Tujuan dari penelitian ini adalah untuk mengetahui pengaruh corporate rebranding, terhadap brand associations, customer satisfaction, company reputation and customer loyalty. Penelitian dilakukan pada Asuransi Jasindo Denpasar. Teknik pengumpulan data menggunakan kuesioner kepada 100 orang nasabah Asuransi Jasindo Denpasar. Data dianalisis dengan teknik analisis data Structure Equation Modelling dengan program AMOS. Hasil penelitian menunjukkan terdapat corporate rebranding berpengaruh positif dan signifikan terhadap brand associations, kepuasan nasabah dan reputasi perusahaan. Selain itu pula terdapat pengaruh positif dan signifikan antara corporate rebranding brand associations, kepuasan nasabah dan reputasi perusahaan terhadap loyalitas nasbaah.
\end{abstract}

Kata kunci: corporate rebranding brand associations, kepuasan nasabah, reputasi perusahaan dan loyalitas nasabah 


\section{PENDAHULUAN}

Perusahaan yang memahami bahwa pemasaran merupakan faktor penting untuk mencapai sukses usaha akan mengetahui adanya cara atau falsafah yang disebut dengan konsep pemasaran (marketing concept). Konsep pemasaran adalah sebuah falsafah bisnis yang menyatakan bahwa pemuasan kebutuhan pelanggan merupakan syarat ekonomi dan sosial bagi kelangsungan hidup suatu perusahaan (Supit dan Darma, 2018). Terdapat tiga unsur pokok yang dilakukan perusahaan dalam melaksanakan konsep pemasaran yaitu benar-benar ingin memperhatikan pelanggan atau berorientasi pada pelanggan, menyusun kegiatan pemasaran secara integral (integrated marketing), serta mendapatkan laba dengan cara memberikan kepuasan kepada pelanggan (Dharmmesta dan Handoko, 2014: 6; Ginantra dkk, 2017).

Lebih lanjut falsafah pemasaran mengalami evolusi dari orientasi internal (inward looking) menuju orientasi eksternal (outward looking) yang direfleksikan dalam suatu konsep pemasaran. Konsep pemasaran berpandangan bahwa kunci untuk mewujudkan tujuan organisasi terletak pada kemampuan organisasi dalam menciptakan, memberikan, dan mengkomunikasikan nilai konsumen (customer value) kepada pasar sasarannya secara lebih efektif dibanding para pesaing. Terdapat tiga elemen kunci yang menentukan kesuksesan implementasi konsep pemasaran yaitu kepuasan konsumen, kualitas layanan dan loyalitas konsumen (Tjiptono et al., 2012: 37).

Menurut Darma (2019) loyalitas konsumen adalah konsep yang subjektif, konsep yang paling baik didefenisikan oleh konsumen itu sendiri, tentu saja ada tingkatan-tingkatan loyalitas. Beberapa konsumen lebih loyal daripada yang lain dan konsumen lebih loyal pada beberapa perusahaan dan lebih dari satu perusahaan. Konsumen yang loyal merupakan aset penting bagi perusahaan, hal ini dapat dilihat dari karakteristik yang dimilikinya, sebagaimana diungkapkan Griffin (2012: 31), konsumen yang loyal memiliki karakteristik diantaranya melakukan pembelian berulang secara teratur, membeli antarlini produk dan jasa, mereferensikan kepada orang lain, dan menunjukkan kekebalan terhadap tarikan dari pesaing. Darma (2018) menyatakan perilaku pembelian ulang seringkali dihubungkan dengan loyalitas brand. Loyalitas brand mencerminkan komitmen psikologis terhadap brand tertentu, sedangkan perilaku pembelian ulang semata-mata menyangkut pembelian brand tertentu yang sama secara berulang kali. Pada prinsipnya, konsep loyalitas konsumen berlaku untuk brand, jasa, organisasi, kategori produk dan juga aktivitas.

Kapferer dalam Muzellec and Lambkin (2016) mengemukakan banyaknya kasus corporate rebranding menunjukkan suatu tantangan konseptual yang menarik bagi disiplin ilmu pemasaran. Bila sebuah brand diputuskan untuk diteruskan eksistensinya, langkah untuk 
mempertahankannya adalah dengan merevitalisasi brand tersebut. Revitalisasi serta reposisi suatu brand melalui perubahan secara bertahap atas proposisi brand dapat dianggap sebagai bagian yang wajar dan wajib dilakukan oleh manajemen brand sebagai tanggapan atas kondisikondisi pasar yang terus berubah (Soehadi, 2015:135).

Gaurav (2014) menyatakan bahwa corporate rebranding merupakan suatu alat yang kuat dan terpercaya dalam mengubah identitas perusahaan, logo, slogan dan iklan agar dapat memberikan brand image baru. Rebranding menjadi pilihan yang baik untuk mengubah persepsi masyarakat dengan memberikan brand image yang baru dari brand sebelumnya. Memahami kondisi aktual sebelum perubahan serta posisi pasar dan persepsi publik yang diinginkan dari sebuah brand, sangat berarti dan penting bagi perusahaan. Sebuah brand merupakan jumlah dari persepsi yang diyakini pelanggan terhadap perusahaan serta tawaran dari perusahaan, di mana target kepuasan pelanggan didapat dari pemenuhan ekspektasi yang dipenuhi dari brand.

\section{TINJAUAN PUSTAKA}

\section{Corporate Rebranding}

Einwiller and Will (2012: 101) berpendapat bahwa corporate rebranding sebagai strategi perubahan yang terencana dan terlaksana dengan sistematis untuk mempertahankan suatu brand image yang baik dan menciptakan brand image baru yang lebih baik. Nesia dan Darma (2015); Lomax and Mador (2016: 84) dalam penelitiannya menyebutkan bahwa faktor-faktor eksternal adalah pendorong yang utama untuk melaksanakan corporate rebranding. Terdapat dua dorongan menyeluruh yang muncul yaitu perubahan struktural perusahaan yang diterapkan dan perhatian atas persepsi-persepsi eksternal terhadap perusahaan serta aktivitas-aktivitasnya. Kedua dorongan menyeluruh untuk melakukan corporate rebranding tersebut mencakup suatu keragaman dari tujuan-tujuan yang lebih terperinci, akan tetapi pada umumnya adalah untuk mengembangkan atau untuk mengkomunikasikan suatu image baru.

Muzellec and Lambkin (2016: 810) ; Hendhana dan Darma (2017) berpendapat bahwa terdapat beberapa faktor yang membuat perusahaan melakukan corporate rebranding dan mengelompokkannya ke dalam empat kategori utama tipe-tipe penggerak utama keputusan untuk melakukan corporate rebranding: 1. Perubahan pada struktur kepemilikan yaitu adanya merger dan akuisisi, spin-off dan demerger, pengalihan kepemilikan dari swasta ke publik, dan sponsorship; 2. Perubahan pada strategi perusahaan yaitu adanya diversifikasi dan divestasi, atau adanya internasionalisasi dan lokalisasi; 3. Perubahan pada posisi kompetisi yaitu adanya 
image yang ketinggalan jaman, tergerusnya posisi pasar, dan persoalan reputasi; 4. Perubahan pada lingkungan eksternal yaitu adanya kewajiban hukum, krisis atau bencana.

\section{Brand Associations}

Keller (2013: 3) mendefinisikan brand image adalah persepsi mengenai suatu brand sebagaimana yang dicerminkan oleh brand association yang tertanam di ingatan konsumen. Terlihat jelas bahwa konsumen menyusun suatu image atas brand tersebut atas dasar asosiasiasosiasi yang telah diingat selama berhubungan dengan brand tersebut. Maka image dari sebuah brand tertentu dapat berbeda antar individu, sebagaimana halnya setiap orang dapat memiliki asosiasi yang berbeda-beda mengenai sebuah brand. Pengertian asosiasi merek yang dikemukakan oleh Aeker (2011: 109) adalah "segala hal yang berkaitan dengan ingatan mengenai merek". Asosiasi akan menjadi faktor penting, jika merek yang produsen miliki mirip dalam hal atribut dengan merek lainnya atau jika perusahaan merupakan hal penting untuk dilihat. Suatu merek akan lebih kuat apabila dilandasi pada banyak pengalaman untuk mengkomunikasikannya.

Keller (2013: 2) memberikan konsep brand knowledge ke dalam dua dimensi brand awareness dan brand image. Brand awareness terdiri dari dua komponen yaitu brand recall dan brand recognition. Brand image terdiri dari dua komponen yaitu type of brand association serta sikap positif, kekuatan dan keunikan dari asosiasi brand (favorability, strength, dan uniqueness of brand association). Brand image yang positif adalah berbagai asosiasi brand sesuai harapan perusahaan sebagai pemilik brand.

\section{Customer Satisfaction}

Kepuasan pelanggan adalah sebagai respon pelanggan terhadap evaluasi ketidaksesuaian yang dipersepsikan antara harapan sebelum pembelian dan kinerja actual produk yang dirasakan setelah pemakaiannya (Wilton, 2014:77; Kanten dan Darma, 2017; Adnyasuari dan Darma, 2017). Hal yang sama juga dikemukakan oleh Kotler, dan Keller (2013:36) menyebutkan satisfaction is a person's feelings of pleasure or disappointment resulting form comparing a product's perceived performance (or oucome) in relation to his expectations, atau kepuasan adalah tingkat perasaan seseorang setelah membandingkan kinerja atau hasil yang dirasakan dibandingkan dengan harapannya. Pelanggan puas bila harapan mereka dipenuhi dan senang bila harapan mereka dilebihi.

Adnyana dan Darma (2015) merumuskan kepuasan pelanggan merupakan evaluasi purnabeli dimana alternatif yang dipilih sekurang-kurangnya sama atau melampaui harapannya. Park (1997) dalam Hasan, (2013:79), menjelaskan kepuasan konsumen merupakan suatu perasaan konsumen sebagai respon terhadap produk batang dan jasa yang 
telah dikonsumsi. Kotler, dan Keller (2013:50) menandaskan bahwa kepuasan pelanggan adalah tingkat perasaan seseorang setelah membandingkan kinerja yang ia rasakan dibandingkan dengan harapan.

\section{Company Reputation}

Folley and Kendrick (2016: 25) berpendapat reputasi adalah faktor penyumbang penting bagi keputusan belanja konsumen. Ketika orang memiliki anggapan baik atas sebuah perusahaan, perusahaan tersebut dapat mengejar lebih banyak peluang secara keseluruhan bagi semua konstituen utamanya bila dibandingkan dengan pesaing terkemuka lainnya. Siswanto Sutojo (2014: 2) mengungkapkan reputasi perusahaan menjadi salah satu pegangan bagi banyak orang dalam mengambil berbagai macam keputusan penting, contoh keputusan tersebut adalah membeli barang atau jasa yang dihasilkan perusahaan, berlangganan, dan merekomendasikan produk perusahaan kepada orang lain. Lebih lanjut Siswanto Sutojo (2014: 3) mau tidak mau, setiap perusahaan mempunyai reputasi di masyarakat. Reputasi itu sendiri mendapat peringkat baik, sedang, atau buruk. Reputasi yang buruk melahirkan dampak negatif bagi operasi bisnis perusahaan dan juga melemahkan kemampuan perusahaan untuk bersaing.

\section{Loyalty}

Loyalitas memberi pengertian yang sama atas loyalitas merek dan loyalitas pelanggan. Memang benar bahwa loyalitas merek mencerminkan loyalitas pelanggan terhadap merek tertentu, tetapi apabila pelanggan dimengerti sama dengan konsumen, maka loyalitas konsumen lebih luas cakupannya daripada loaylitas merek, karena loyalitas konsumen mencakup loyalitas terhadap merek (Dharmmesta, 2012: 75). Loyalitas adalah tentang presentase dari orang yang pernah membeli dalam kerengka waktu tertentu dan melakukan pembelian ulang sejak pembelian yang pertama.

Dalam mengukur kesetiaan, Zeithaml et al (2014:38) ; Widana dan Darma (2018) menyatakan dengan beberapa atribut, yaitu: 1) mengatakan hal yang positif tentang perusahaan kepada orang lain; 2) merekomendasikan perusahaan kepada orang lain yang meminta saran; 3) mempertimbangkan bahwa perusahaan merupakan pilihan pertama dalam melakukan pembelian jasa; 4) melakukan lebih banyak bisnis atau pembelian dengan perusahaan beberapa tahun mendatang.

\section{Kerangka Konseptual}

Kinerja yang baik merupakan harapan bagi semua perusahaan dan institusi yang memperkerjakan pegawai, sebab kinerja pegawai ini pada akhirnya diharapkan dapat meningkatkan kinerja pemsahaan secara keseluruhan. Kinerja pegawai akan optimal jika 
didukung oleh hadirnya faktor-faktor kepuasan kerja yang lingkungan kerja yang kondusif, kesempatan promosi serta semangat kerja pegawai. Berdasarkan penjelasan diatas dan teoriteori yang telali dikemukakan maka dapat digambarkan suatu model seperti pada gambar berikut ini.

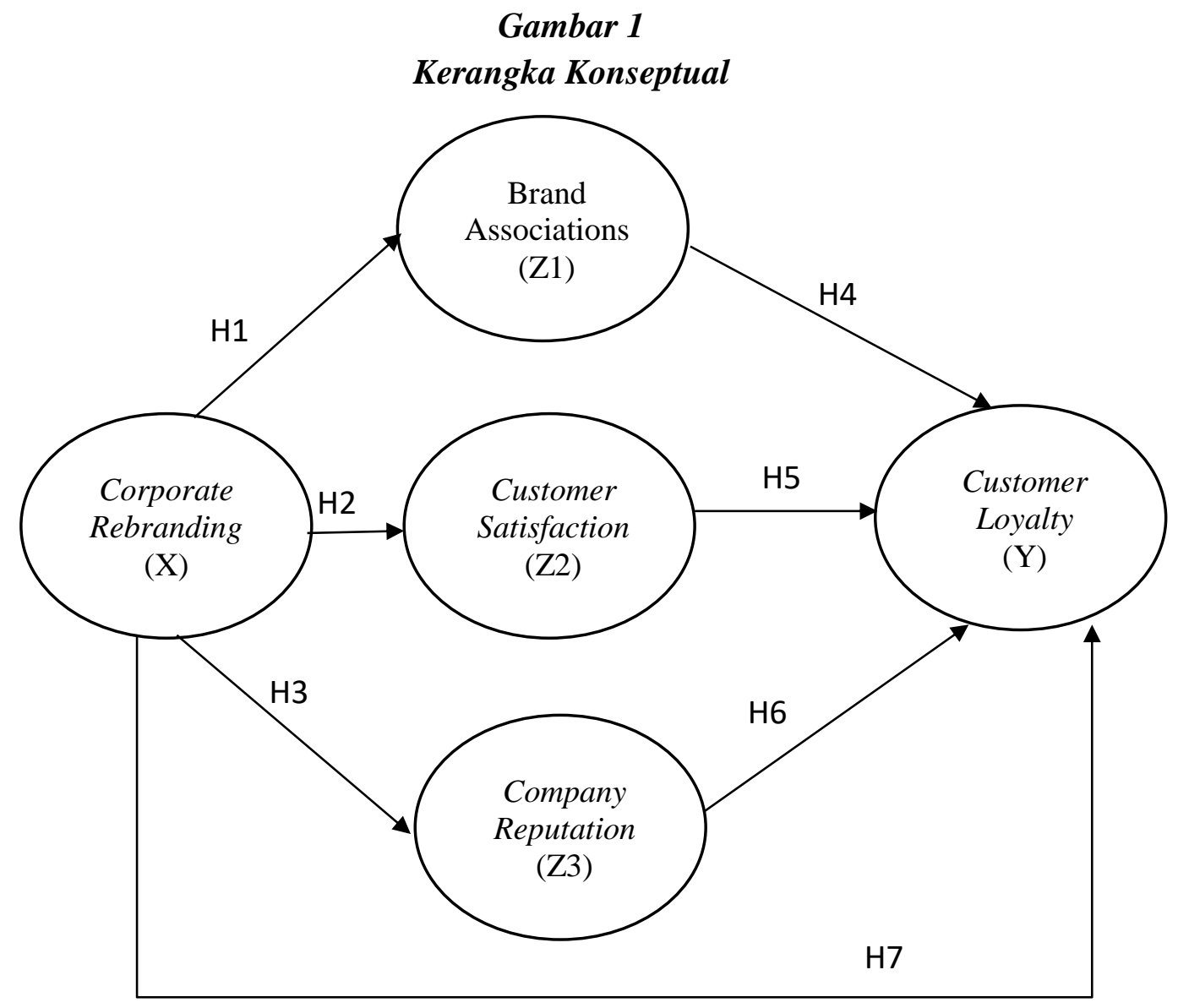

\section{METODE PENELITIAN}

Penelitian ini dilakukan pada Asuransi Jasindo Denpasar. Teknik pengumpulan data menggunakan kuesioner kepada 100 orang pegawai. Data dianalisis dengan Structural Equation Modelling (SEM) dengan program AMOS.

\section{HASIL DAN PEMBAHASAN}

\section{Hasil Penelitian}

Proses pengujian data telah dilakukan sesuai dengan prosedur yang umum berlaku. Analisis validitas, reliabilitas, dan normalitas data, seluruhnya telah memenuhi syarat. Untuk selanjutnya dilakukan pengolahan data. hasil pengolahan Structural Equation Modelling (SEM) seperti gambar berikut ini. 


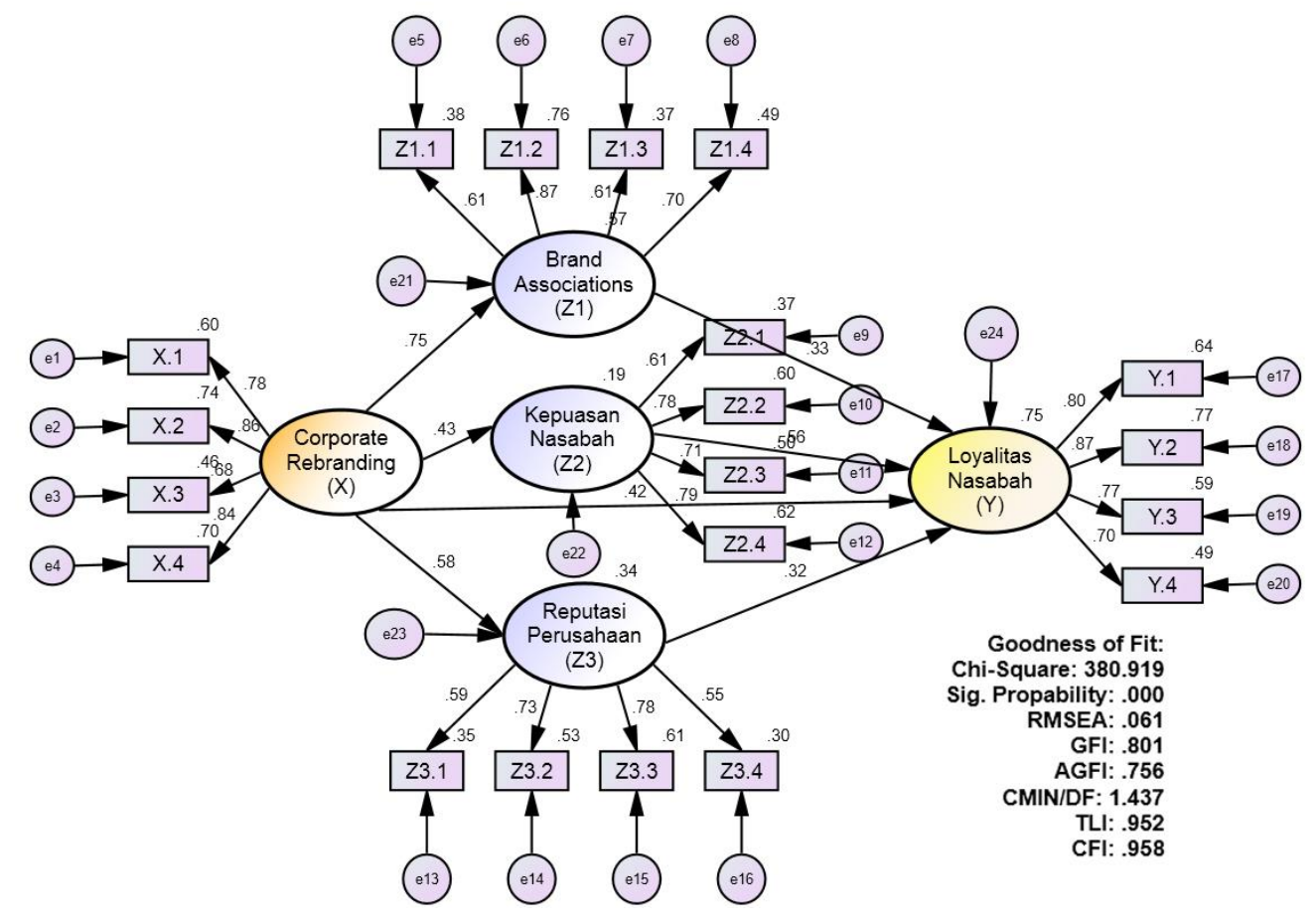

Gambar 2

Hasil Full Model Pengaruh Corporate Rebranding, Brand Associations, Kepuasan Nasabah, Reputasi Perusahaan dan Loyalitas Nasabah

Tabel 1 Regression Weights

\begin{tabular}{|c|c|c|c|c|c|c|c|}
\hline & & Estimate & $\begin{array}{r}\text { Standarized } \\
\text { Estimate }\end{array}$ & S.E. & C.R. & $\mathrm{P}$ & Ket \\
\hline $\mathrm{Z} 1.1$ & $<---\quad$ Z1 & 1.000 & .614 & & & & Valid \\
\hline $\mathrm{Z} 1.2$ & $<---\quad$ Z1 & 1.609 & .872 & .255 & 6.303 & $* * *$ & Valid \\
\hline Z1.3 & $<---\quad \mathrm{Z1}$ & 1.037 & .611 & .212 & 4.890 & $* * *$ & Valid \\
\hline Z1.4 & $<---\quad$ Z1 & 1.212 & .700 & .219 & 5.531 & $* * *$ & Valid \\
\hline X.4 & $<---\quad X$ & 1.000 & .837 & & & & Valid \\
\hline X.3 & $<---\quad X$ & .682 & .677 & .094 & 7.283 & $* * *$ & Valid \\
\hline $\mathrm{X} .2$ & $\begin{array}{ll}<--- & X \\
\end{array}$ & 1.015 & .861 & .103 & 9.876 & $* * *$ & Valid \\
\hline X.1 & $<---\quad X$ & .795 & .776 & .090 & 8.829 & $* * *$ & Valid \\
\hline Y.1 & $\begin{array}{ll}--- & Y\end{array}$ & 1.000 & .802 & & & & Valid \\
\hline Y.2 & $\begin{array}{ll}<--- & Y \\
\end{array}$ & 1.070 & .875 & .105 & 10.177 & $* * *$ & Valid \\
\hline Y.3 & $<---\quad Y$ & 1.008 & .766 & .118 & 8.527 & $* * *$ & Valid \\
\hline Y.4 & $\begin{array}{ll}<--- & Y \\
\end{array}$ & .874 & .698 & .113 & 7.733 & $* * *$ & Valid \\
\hline $\mathrm{Z} 2.1$ & $\begin{array}{ll}<-- & \text { Z2 }\end{array}$ & 1.000 & .610 & & & & Valid \\
\hline $\mathrm{Z} 2.2$ & $<---\quad$ Z2 & 1.192 & .776 & .200 & 5.951 & $* * *$ & Valid \\
\hline $\mathrm{Z} 2.3$ & $\begin{array}{l}<-- \\
\text { Z2 }\end{array}$ & 1.038 & .706 & .203 & 5.111 & $* * *$ & Valid \\
\hline $\mathrm{Z} 2.4$ & $<---\quad$ Z2 & 1.232 & .786 & .221 & 5.584 & $* * *$ & Valid \\
\hline $\mathrm{Z} 3.4$ & $<---\quad$ Z3 & 1.000 & .551 & & & & Valid \\
\hline $\mathrm{Z} 3.3$ & $\begin{array}{l}--- \\
\text { Z3 }\end{array}$ & 1.027 & .784 & .219 & 4.696 & $* * *$ & Valid \\
\hline $\mathrm{Z} 3.2$ & $<---\quad$ Z3 & 1.315 & .729 & .263 & 4.995 & *** & Valid \\
\hline Z3.1 & $\begin{array}{l}<-- \\
\end{array}$ & 1.164 & .587 & .274 & 4.248 & $* * *$ & Valid \\
\hline
\end{tabular}


Berdasarkan data pada tabel $1 \mathrm{di}$ atas terlihat bahwa tidak ada indikator yang memiliki standardized estimate (regression weights) berupa loading factor atau lamda $(\lambda)<0.5$. Semua indikator memiliki nilai kritis C.R. > 2,00 dan memiliki probabilitas lebih kecil dari 0,05 (***). Dengan demikian dapat dikatakan bahwa semua indikator adalah adalah valid membentuk variabel laten.

Tabel 2 Evaluasi Goodness of Fit

\begin{tabular}{|l|c|c|c|}
\hline \multicolumn{1}{|c|}{ Goodness of Fit Index } & $\begin{array}{c}\text { Cut-of } \\
\text { Value }\end{array}$ & $\begin{array}{c}\text { Hasil } \\
\text { Model }\end{array}$ & Keterangan \\
\hline Chi-square $\left(\chi^{2}\right)$ & $\begin{array}{c}\text { Diharapkan } \\
\text { kecil }\end{array}$ & 380,919 & Kurang baik \\
\hline $\begin{array}{l}\text { Relatitive Chi-square } \\
\left(\chi^{2} / \mathrm{df}\right)\end{array}$ & $\leq 3,00$ & $\left.1,437^{*}\right)$ & Baik \\
\hline Probability & $>0,05$ & 0,000 & Kurang baik \\
\hline RMSEA & $\leq 0,08$ & $\left.0,061^{*}\right)$ & Baik \\
\hline GFI & $\geq 0,90$ & $0,801+)$ & Marginal \\
\hline AGFI & $\geq 0,90$ & $0,756+)$ & Marginal \\
\hline CFI & $\geq 0,95$ & $\left.0,958^{*}\right)$ & Baik \\
\hline TLI & $\geq 0,95$ & $\left.0,952^{*}\right)$ & baik \\
\hline
\end{tabular}

Memperhatikan nilai cut-of-value dan goodness of fit hasil model pada tabel 2 di atas, empat kriteria yang terpenuhi dari delapan kriteria yang dipakai. Kriteria yang terpenuhi adalah Relatitive Chi-square ( $\left.\chi^{2} / \mathrm{df}\right)$, RMSEA, CFI dan TLI dan 2 marginal yaitu GFI dan AGFI. Karena sudah lebih dari dua kriteria dari delapan kriteria yang disyaratkan yang memenuhi syarat, maka model di atas dapat dinyatakan sudah baik.

Tabel 3Regression Weights Corporate Rebranding, Brand Associations, Kepuasan Nasabah, Reputasi Perusahaan dan Loyalitas Nasabah

\begin{tabular}{|lll|r|r|r|r|c|c|}
\hline & & Estimate & $\begin{array}{r}\text { Standarized } \\
\text { Estimate }\end{array}$ & S.E. & C.R. & $\mathrm{P}$ & Ket \\
\hline $\mathrm{Z1}$ & $<---$ & $\mathrm{X}$ & .407 & .755 & .077 & 5.296 & $* * *$ & Sig \\
\hline $\mathrm{Z3}$ & $<---$ & $\mathrm{X}$ & .361 & .582 & .088 & 4.095 & $* * *$ & Sig \\
\hline $\mathrm{Z} 2$ & $<---$ & $\mathrm{X}$ & .287 & .430 & .088 & 3.255 & .001 & Sig \\
\hline $\mathrm{Y}$ & $<---$ & $\mathrm{Z} 1$ & .200 & .333 & .208 & 2.364 & .020 & Sig \\
\hline $\mathrm{Y}$ & $<---$ & $\mathrm{Z} 2$ & .685 & .562 & .166 & 4.122 & $* * *$ & Sig \\
\hline $\mathrm{Y}$ & $<---$ & $\mathrm{X}$ & .257 & .419 & .122 & 3.092 & .004 & Sig \\
\hline $\mathrm{Y}$ & $<---$ & $\mathrm{Z} 3$ & .417 & .318 & .184 & 2.273 & .023 & Sig \\
\hline
\end{tabular}

Dari tabel 3 di atas dapat dilihat bahwa seluruh nilai $C R>2,000$ dan probability $<0,05$, ini berarti pengaruh seluruh variabel eksogen terhadap variabel endogen adalah signifikan. 
Analisis Model Pengukuran Determinasi

Tabel 4 Squared Multiple Correlations

\begin{tabular}{|l|r|}
\hline & Estimate \\
\hline $\mathrm{Z} 3$ & .339 \\
$\mathrm{Z} 2$ & .185 \\
$\mathrm{Z1}$ & .570 \\
$\mathrm{Y}$ & .749 \\
\hline
\end{tabular}

Berdasarkan data pada tabel 4 di atas tampak bahwa besarnya nilai Squared Multiple Correlations untuk variabel Squared Multiple Correlations untuk variabel Brand Associations (Z1) sebesar 0,570, Kepuasan Nasabah (Z2) sebesar 0,185, Reputasi Perusahaan (X3) sebesar 0,339 dan Loyalitas Nasabah (Y) sebesar 0,749. Menurut Ferdinand (2014:114) nilai Squared Multiple Correlations identik dengan $\mathrm{R}^{2}$ pada SPSS. Besarnya nilai determinasi (D) adalah Squared Multiple Correlations x $100 \%$. Sehingga besarnya koefesien determinasi (D) masing-masing variabel adalah sebagai berikut:

1. Brand Associations (Z1) sebesar $0,570 \times 100 \%=57 \%$

2. Customer Satisfaction (Z2) sebesar 0,185 x 100\% =18,5\%

3. Company Reputation (Z3) sebesar 0,339 x 100\% = 33,9\%

4. Customer Loyalty (Y) sebesar 0,749 $=74,9 \%$

\section{Pembahasan}

\section{Pengaruh Corporate Rebranding Terhadap Brand Associations}

Diterimanya hipotesis pertama yang menyatakan Semakin baik corporate rebranding maka semakin baik brand associations Asuransi Jasindo Denpasar sejalan dengan pendapat Aeker, (2011:109) yang menyatakan asosiasi merek yang adalah segala hal yang berkaitan dengan ingatan mengenai merek. Asosiasi akan menjadi faktor penting, jika merek yang produsen miliki mirip dalam hal atribut dengan merek lainnya atau jika perusahaan merupakan hal penting untuk dilihat. Suatu merek akan lebih kuat apabila dilandasi pada banyak pengalaman untuk mengkomunikasikannya.

Pendapat lain juga menyatakan hal yang sama, Muzellec and Lambkin (2016: 804) menjelaskan bahwa corporate rebranding sebagai penciptaan sebuah nama, istilah, simbol serta desain. Kombinasi dari hal-hal tersebut yang baru untuk sebuah brand yang sudah mapan dengan maksud mengembangkan suatu posisi yang baru dan berbeda di 
benak para pemangku kepentingan dan pesaing. Corporate rebranding yang dilakukan Eiger tentu saja akan menghilangkan image lama dan mengganti dengan image yang baru di benak konsumen. Hasil penelitian Risman Hilmansyah (2013) menunjukkan bahwa brand image Sony Xperia smartphone cukup baik dan rebranding process berpengaruh positif terhadap brand image Sony-Xperia smartphone sebesar 79\%. Hasil penelitian tersebut dapat disimpulkan bahwa rebranding yang dilakukan oleh Sony Xperia berpengaruh positif terhadap brand image. Keller (2013: 66) menyatakan bahwa brand image yang positif terbentuk dari asosiasi-asosiasi dari brand yang kuat, menguntungkan dan unik. Sehingga hasil penelitian tersebut dapat menjadi acuan penelitian ini bahwa corporate rebranding berpengaruh terhadap brand association.

\section{Pengaruh Corporate Rebranding Terhadap Customer Satisfaction}

Diterimanya hipotesis kedua yang menyatakan Semakin baik corporate rebranding maka semakin tinggi kepuasan nasabah Asuransi Jasindo Denpasar sejalan dengan pendapat Argenti and Druckenmiller, (2014) yan menyatakan corporate rebranding menciptakan asosiasi-asosiasi dalam benak pelanggan seperti yang diharapkan oleh suatu perusahaan serta harapan-harapan dalam pikiran konsumen mengenai apa yang dapat diberikan oleh perusahaan tersebut, oleh sebab itu dengan memenuhi harapan-harapan tersebut pelanggan akan merasa puas. Hasil penelitian ini sejalan pula dengan hasil penelitian yang dilakukan oleh Krisprimandoyo (menemukan 2015) pengaruh langsung antara variabel corporate rebranding (X) dengan variabel kepuasan konsumen (Y2) sebesar 0,405 dengan arah positif. Ini artinya bahwa semakin baik corporate rebranding maka semakin tinggi kepuasan konsumen.

\section{Pengaruh Corporate Rebranding Terhadap Company Reputation}

Diterimanya hipotesis ketiga yang menyatakan Semakin baik corporate rebranding maka semakin baik reputasi perusahaan Asuransi Jasindo Denpasar sejalan dengan pendapat Muzellec and Lambkin (2016: 804) menjelaskan bahwa corporate rebranding sebagai penciptaan sebuah nama, istilah, simbol serta desain. Kombinasi dari hal-hal tersebut yang baru untuk sebuah brand yang sudah mapan dengan maksud mengembangkan suatu posisi yang baru dan berbeda di benak para pemangku kepentingan dan pesaing. Corporate rebranding yang dilakukan Eiger adalah merubah logo dan slogan lama dan menggantinya dengan tampilan yang lebih baru dan fresh dan melakukan repositioning dengan perluasan pangsa pasar. Sedangkan menurut Folley and Kendrick (2016:199) 
reputasi perusahaan adalah berbagai persepsi keseluruhan terhadap perusahaan, brand, produk, atau jasa yang dipegang oleh stakeholder diluar perusahaan. Dapat dikaitkan bahwa corporate rebranding yang dilakukan Eiger akan mempengaruhi reputasi perusahaan dalam hal persepsi terhadap brand maupun produk Eiger yang selama ini sudah ada di benak konsumen. Hasil ini sejalan pula dengan hasil penelitian yang dilakukan oleh Kriprimandoyo (2015) membuktikan bahwa corporate rebranding yang dilakukan PT Citraland berpengaruh terhadap Reputasi perusahaan. Hasil dari penelitian tersebut menunjukkan pengaruh langsung antara variabel corporate rebranding $(\mathrm{X})$ dengan variabel reputasi perusahaan (Y) sebesar 0.215 dengan arah positif.

\section{Pengaruh Brand Associations Terhadap Loyalty}

Diterimanya hipotesis keempat yang menytakan Semakin baik pengaruh brand associations maka semakin baik loyalitas nasabah Asuransi Jasindo Denpasar sejalan dengan pendapat Aeker (2011: 109) yang menyatakan "segala hal yang berkaitan dengan ingatan mengenai merek". Asosiasi akan menjadi faktor penting, jika merek yang produsen miliki mirip dalam hal atribut dengan merek lainnya atau jika perusahaan merupakan hal penting untuk dilihat. Suatu merek akan lebih kuat apabila dilandasi pada banyak pengalaman untuk mengkomunikasikannya. Pengalaman pengalaman positif mengenai merek akan menghasilkan brand image positif di benak konsumen yang mana akan menarik konsumen untuk mengkonsumsi atau menggunakan produk itu kembali. Sedangkan menurut Kotler dan Keller (2013: 190), loyalitas atau kesetiaan juga didefenisikan sebagai komitmen yang dipegang kuat untuk membeli atau berlangganan lagi produk atau jasa tertentu di masa depan meskipun ada situasi dan usaha pemasaran yang berpotensi menyebabkan perubahan perilaku.

Hasil ini sejalan pula dengan hasil penelitian yang dilakukan oleh Juniarty $\mathrm{R}$ (2012) menunjukkan bahwa Brand Association yang berkaitan dengan Attribute, Brand Attitude dan Benefit secara bersama-sama berpengaruh signifikan terhadap loyalitas konsumen (Y) pada handphone merek nokia. Variabel yang paling berpengaruh adalah variabel Benefit. Penelitian lain oleh Florentinus Hendi Hera (2013) menghasilkan hasil yang sama. Dalam penelitian tersebut dpat disimpulkan terdapat pengaruh positif dan signifikan brand Association terhadap loyalitas pelanggan Kecap manis merek ABC pada taraf uji signifikansi 0,05 artinya jika brand Association semakin baikmaka loyalitas pelanggan kecap manis merek $\mathrm{ABC}$ akan semakin meningkat. Kedua hasil penelitian 
tersebut dapat menjadi acuan penelitian ini bahwa Brand Association berpengaruh terhadap loyalitas konsumen.

\section{Pengaruh Customer Satisfaction Terhadap Loyalty}

Diterimanya hipotesis kelima yang menyatakan Semakin tinggi kepuasan nasabah maka semakin tinggi loyalitas nasabah Asuransi Jasindo Denpasar sejalan dengan pendapat Menurut Pohan (2014:21), kepuasan konsumen adalah suatu tingkat perasaan konsumen yang timbul sebagai akibat dari perbandingan antara kesannya terhadap kinerja atau hasil suatu produk dan harapan-harapannya. Kepuasan yang dirasakan oleh konsumen secara tidak langsung menimbulkan loyalitas konsumen terhadap produk tersebut. Nidyantri dan Suryawardani (2016) dalam penelitiannya menemukan bahwa satisfaction memiliki pengaruh yang signifikan dengan loyalty produk edamame dan trust memiliki pengaruh yang signifikan dengan loyalty produk edamame dengan probability 0,000 atau $p$ lebih kecil dari 0,05 , artinya bahwa semakin tinggi tingkat kepuasan dan kepercayaan konsumen yang dirasakan, maka semakin tinggi pula loyalitas konsumen untuk membeli kembali produk edamame (rebuy), begitu juga sebaliknya.

\section{Pengaruh Company Reputation Terhadap Loyalty}

Diterimanya hipotesis keenam yang menyatakan Semakin baik reputasi perusahaan maka semakin tinggi loyalitas nasabah Asuransi Jasindo Denpasar sejalan dengan pendapat Folley and Kendrick (2016:199) yang menyatakan reputasi perusahaan adalah berbagai persepsi keseluruhan terhadap perusahaan, brand, produk, atau jasa yang dipegang oleh stakeholder diluar perusahaan. Reputasi baik suatu perusahaan yang memasarkan produk atau jasa menjadi faktor penting dalam peningkatan kepercayaan konsumen. Loyalitas nasabah juga terkait dengan reputasi perusahaan. Jika perusahaan memiliki reputasi yang baik, maka konsumen akan menunjukkan sikap menyukai perusahaan tersebut dan loyal terhadap produk dan jasa perusahaan yang bersangkutan. Sebuah penelitian oleh tari (2015) menunjukkan bahwa hasil tes pengujian hipotesis. $\mathrm{t}$ hitung $(22,558)>$ t Ini menunjukkan bahwa reputasi perusahaan mempengaruhi loyalitas pelanggan. Besarnya reputasi perusahaan pada loyalitas pelanggan di PT Insurance BSAM Branch Pekanbaru adalah 84\%. tabel (1,66071). 


\section{Pengaruh Corporate Rebranding Terhadap Loyalty}

Diterimanya hipotesis ketujuh yang menyatakan Semakin baik corporate rebranding maka semakin tinggi loyalitas nasabah Asuransi Jasindo Denpasar sejalan dengan pendapat Kotler dan Keller (2013: 190), yang menyatakan bahwa loyalitas atau kesetiaan juga didefenisikan sebagai komitmen yang dipegang kuat untuk membeli atau berlangganan lagi produk atau jasa tertentu di masa depan meskipun ada situasi dan usaha pemasaran yang berpotensi menyebabkan perubahan perilaku. Muzellec and Lambkin (2016: 804) menjelaskan bahwa corporate rebranding sebagai penciptaan sebuah nama, istilah, simbol serta desain.

Hasil ini sejalan pula dengan hasil penelitian yang dilakukan oleh Anggoro (2013) menunjukkan ada hubungan positif antara rebranding yang dilakukan oleh produk larutan penyegar Cap Kaki Tiga menjadi Cap Badak terhadap loyalitas konsumen. Variabel bebas membuat ulang kesadaran merek memiliki pengaruh signifikan terhadap loyalitas pelanggan dengan t-hitung $>$ t-tabel dan nilai signifikan $>0,05$. Sedangkan memilih ulang sebuah merek dan menciptakan ulang citra merek memiliki pengaruh signifikan terhadap loyalitas pelanggan.

\section{PENUTUP}

Corporate rebranding berpengaruh positif dan signifikan terhadap brand associations, yang artinya bahwa semakin baik corporate rebranding maka semakin baik brand associations Asuransi Jasindo Denpasar. Corporate rebranding berpengaruh positif dan signifikan terhadap Customer Satisfaction, yang artinya semakin baik corporate rebranding maka semakin tinggi Customer Satisfaction Asuransi Jasindo Denpasar. Corporate rebranding berpengaruh positif dan signifikan terhadap Company Reputation, yang artinya semakin baik corporate rebranding maka semakin baik Company Reputation Asuransi Jasindo Denpasar. Brand associations berpengaruh positif dan signifikan terhadap Customer Loyalty, yang artinya semakin baik brand associations maka semakin baik Customer Loyalty Asuransi Jasindo Denpasar. Customer Satisfaction berpengaruh positif dan signifikan terhadap Customer Loyalty, yang artinya semakin tinggi Customer Satisfaction maka semakin tinggi Customer Loyalty Asuransi Jasindo Denpasar. Company Reputation berpengaruh positif dan signifikan terhadap Customer Loyalty, yang artinya semakin baik Company Reputation maka semakin tinggi Customer Loyalty Asuransi Jasindo Denpasar. Corporate rebranding berpengaruh positif dan signifikan terhadap Customer Loyalty, yang artinya semakin baik corporate rebranding maka semakin tinggi Customer Loyalty Asuransi Jasindo Denpasar. 


\section{DAFTAR PUSTAKA}

Arief (2016). Pemasaran Jasa \& Kualitas Pelayanan, Bagaimana Mengelola Pelayanan Agar Memuaskan Pelanggan. Malang: Bayumedia Publishing.

Aaker, D.A. (2011). Managing Brand Equity - Capitalizing on the Value of a Brand Name. New York: The Free Press.

Adnyana, R., and Darma, G.S. (2015). Strategi Marketing Mix, Yield Management, Customer Satisfaction and Occupancy Rate, Jurnal Manajemen \& Bisnis, 12 (1): 92-115.

Adnyasuari, P.A.S., and Darma, G.S. (2017). Technology Acceptance Model dan ESatisfaction in Mobile Banking, Jurnal Manajemen \& Bisnis, 14 (2): 1-12.

Barnes, J.G. (2013). Secrets of Customer Relationship Management (Rahasia Manajemen Hubungan Pelanggan). Jakarta: Andi.

Barata, A.A. (2013). Dasar-Dasar Pelayanan Prima. Jakarta: PT. Elex Media Komputindo.

Darma, G.S. (2019). Kacamata Media, Kesuksesan Bersyarat. Indonesia: Pustaka Larasan Press.

Darma, G.S. (2018). Seuntai Pesan, Menjawab Zaman. Indonesia: Pustaka Larasan Press.

Dharmmesta, B.S., dan Hani Handoko. (2014). Manajemen Pemasaran: Analisis Perilaku Konsumen, Cetakan Keempat. Yogyakarta: BPFE.

Darmadi, H. (2014). Metode Penelitian Pendidikan dan Sosial. Bandung: Alfabeta.

Einwiller, S., and Markus Will. (2012). Towards an Integrated Approach to Corporate Branding - An Empirical Study, Corporate Communications, 7 (2): 100-110.

Ferdinand, A. (2014). Structural Equation Modeling. Edisi 4. Semarang: BP Undip.

Folley, J., and Kendrick Julie. (2016). Balanced Brand. Strategi Memenangkan Pasar Dengan Menyeimbangkan Kekuatan Brand Dan Reputasi Perusahaan. Terjemahan Oleh Arfan Achihar. Jakarta: Transmedia.

Fombrun, C.J., and Cess Van Riel. (2014). Fame and Fortune: How Successful Companies Build Winning Reputation, Upper Saddle River. NJ: Financial Times Prentice Hall.

Gaurav, K. (2014). Rebranding: Concept, Cases and Applications. Hyderabad: The Icfai University Press.

Ginantra, K.G., Lestari, N.P.N.E., Gorda, A.A.N.E.S., and Darma, G.S. (2017). Effects of Promotion, Product Quality, Brand Image and Price on Customer Satisfaction and Brand Switching Decision, International Journal of Management and Economics Invention, 3 (12): 1514-1523.

Griffin, J. (2012). Customer Loyalty: How to Earn It, How to Keep It, Edisi Terjemahan. Jakarta: Erlangga. 
Hasan, A. (2013). Marketing, Edisi Terbaru. Yogyakarta: Med Pressindo.

Hendhana, S., and Darma, G.S. (2017). Service Quality Rumah Sakit dan Efeknya terhadap Patient Satisfaction, Perceived Value, Trust, dan Behavioral Intention, Jurnal Manajemen \& Bisnis, 14 (1): 37-55.

Indrawan, R., dan Yaniawati R.P. (2014). Metodelogi Penelitian Kuantitatif, Kualitatif dan Campuran Untuk Manajemen, Pembangunan dan Pendidikan. Bandung: PT. Refika Aditama.

Kanten, I.K., and Darma, G.S. (2017). Consumer Behaviour, Marketing Strategy, Customer Satisfaction, and Business Performance, Jurnal Manajemen \& Bisnis, 14 (2): 143-165.

Kotler, P., Keller Kevin Lane. (2013). Manajemen Pemasaran, Edisi 12. Jakarta: PT. Indeks.

Keller, K.L. (2013). Managing Brand for the Long Run: Brand Reinforcement and Revitalization Strategies, California Management Review, 41 (3): 102-124.

Laksana, F. (2012). Manajemen Pemasaran, Pendekatan Praktis. Yogyakarta: Graha Ilmu.

Lomax, W., and Martha Mador. (2016). Corporate Rebranding: From normative models to knowledge management, Journal of Brand Management, 14: 82-95.

Lambkin, M. (2016). Corporate Rebranding: Distroying, Transfering or Creating Brand Equity.

Muzellec, L., and Mary Lambkin and Manus Doogan. (2016). Corporate Rebranding: An Exploratory Review, Irish Marketing Review, 16 (2): 31-40.

Nesia, A., and Darma, G.S. (2015). Diversification Analyzes the Concept of Branding and Promotion to Company Performance, Jurnal Manajemen \& Bisnis, 12 (2): 125-171.

Nidyatari, N.M.M., dan Suryawardani, I.G.A.O. (2016) Pengaruh Kepuasan dan Kepercayaan Terhadap Loyalitas Konsumen Kedelai Jepang Edaname Pendekatan Structural Equation Modelling, E-Jurnal Agribisnis Agrowisata, 5 (1). ISSN: 2301-6523.

Oliver (2015). Whence Consumer Loyalty ?, Journal of Marketing, 63: 33-44.

Pohan, I. (2014). Jaminan Mutu Layanan Kesehatan: Dasar-Dasar Pengertian dan Penerapan. Jakarta: Buku Kedokteran EGC.

Soehadi, A.W. (2015). Effective Branding: Konsep dan Aplikasi Pengembangan Merek yang Sehat dan Kuat, Cetakan 1. Bandung: Quantum Bisnis dan Manajemen.

Supranto, J. (2011). Pengukuran Tingkat Kepuasan Pelanggan Untuk Menaikkan Pangsa Pasar, Edisi Baru. Jakarta: Rineka Cipta.

Sugiyono. (2013). Metode Penelitian Kuantitatif Kualitatif dan R\&D. Bandung: Alfabeta.

Supit, H.A.M., and Darma, G.S. (2018). Aplikasi Mobile Trading Monex Guna Mendukung Customer Relationship Management, Jurnal Manajemen \& Bisnis, 15 (1): 46-60. 
Solimun. (2006). Pemodelan Persamaan Struktural Pendekatan PLS dan SEM, Aplikasi Software Smart PLS dan Amos. Program Pascasarjana Universitas 17 Agustus 1945, Surabaya.

Siswanto, S. (2014). Membangun Citra Perusahaan, PT. Damar Mulia Pustaka, Jakarta

Tjiptono, F. (2014). Service Management Mewujudkan Layanan Prima. Yogjakarta: Andi.

Tjiptono, F., Gregorius Chandra, Dadi Adriana. (2013). Pemasaran Strategik. Yogyakarta: Andi.

Tjiptono, F., Gregorius Chandra. (2012). Service, Quality Satisfaction. Edisi 2, Yogyakarta: Andi.

Wilton. (2014). Kepuasan Pelanggan. Jilid 2. Edisi Ketiga. Jakarta: PT. Indeks Kelompok Gramedia.

Widana, I.W., and Darma, G.S. (2018). Branding Denpasar Smart City Guna Meningkatkan Kunjungan Wisatawan, Jurnal Manajemen \& Bisnis, 15 (1): 176-199.

Zeithmal, V.A., Mry Jo Bitner. (2013). Service Marketing: Integrating Customer Focus A Cross The Firm. Second Edtiion. New York: Hill. McGraw. 